\title{
Návrh způsobu skladování přípravků
}

\author{
Miroslav Bednár ${ }^{1}$, Michal Šimon ${ }^{1}$ \\ 1 Západočeská univerzita v PIzni, Fakulta strojní, Katedra průmyslového inženýrství a \\ managementu \\ Univerzitní 8, 306 14, Plzeň, Česká republika \\ bednarm@kpv.zcu.cz \\ simon@kpv.zcu.cz
}

\begin{abstract}
Anotace: Článek se zabývá navržením způsobu skladování svařovacích prípravků. Pro realizaci navržení bylo nejprve nutné provést analýzu současného způsobu skladování prípravků, dále pak zvolit vhodného dodavatele pro vybraný skladovací systém, navrhnout parametry skladovacího systému s ohledem na skladované prípravky a navrhnout bezpečnostní opatření. Na závěr je výsledná varianta porovnávána s původním stavem.
\end{abstract}

\section{1 Úvod}

Článek je zaměřen na navržení vhodného způsobu skladování pro svařovací prípravky. Pro skladování přípravků je možné zvolit několik skladovacích systémů. Zavedením tohoto systému by mělo být dosaženo úspory místa na výrobní hale, které by bylo možné využít pro navýšení výroby.

Aby bylo možné navrhnout zlepšení, je nejprve potřeba poznat původní stav. $Z$ toho důvodu byla provedena analýza původního stavu. $V$ této části byl zanalyzován původní zpưsob skladování svařovacích prípravků. Při analyzování současného způsobu skladování, byly taktéž zanalyzovány prostory pưvodního stavu. Posledním bodem analýzy současného stavu byla analýza všech svařovacích přípravků.

Po prvotní analýze již bylo potřeba určit nejvhodnější skladovací systém. Po tomto určení bylo možné prozkoumat trh s dodavateli, kteři tento skladovací systém zavedou na halu výroby. Dále bylo nutné využít prvotní analýzu současného stavu pro analýzu rozmístění svařovacích př́ípravků do zvoleného skladovacího systému. Posledním krokem je navržení vhodných bezpečnostních prvků, které by zabránily poničení zvoleného systému.

V poslední části článku je vyhodnocení navržené varianty skladovacího systému oproti původnímu způsobu skladování svařovacích přípravků.

\section{Analýza současného stavu}

Tato kapitola popisuje počáteční analýzu současného stavu skladování prípravků ve společnosti. Tato analýza je základním kamenem pro navržení vhodné technologie a podmínek pro skladování svařovacích přípravků na 
hale. Tyto přípravky jsou uzpůsobené ke svařování různých dílů karoserie, nebo podvozku autobusů. Svařovací prípravky slouží k ustavení a poskládání svařence před svařením. Tyto přípravky urychlují a zjednodušují výrobu svařenců.

V současném stavu se na hale výroby vyskytuje velké množství svařovacích prípravků, které mají různé tvary a rozměry. Cílem analýzy současného stavu bylo zjistit složení svařovacích přípravků a jejich současného skladování. Současný stav je možné popsat $v$ několika bodech:

- Současný stav je takový, že veškeré prípravky jsou $v$ regálech na pracovištích, nebo volně ložené a dochází k jejich hledání

- Prípravky se používají s různou četností

- Některé z prrípravků se na začátku přištího roku odstraní z důvodu nevyužívání

Pro manipulaci s prípravky jsou určeni 3 manipulanti na každou směnu. Jejich náplň práce je velice proměnlivá v závislosti na potřebách výroby. Jako hlavní činnosti těchto manipulantů jsou zásobování svařovacích pracovišt' svařovacími prrípravky, zásobování pracovišt' materiálem a odvážení odpadu.

$\checkmark$ současnosti jsou svařovací prípravky umístěny $v$ klasickém regálovém skladu, který se skládá ze tří regálů. Tyto regály se nachází prímo na hale výroby. Tyto regály zabírají poměrně velkou plochu. Pro manipulaci s príipravky se používají elektrické vysokozdvižné vozíky.
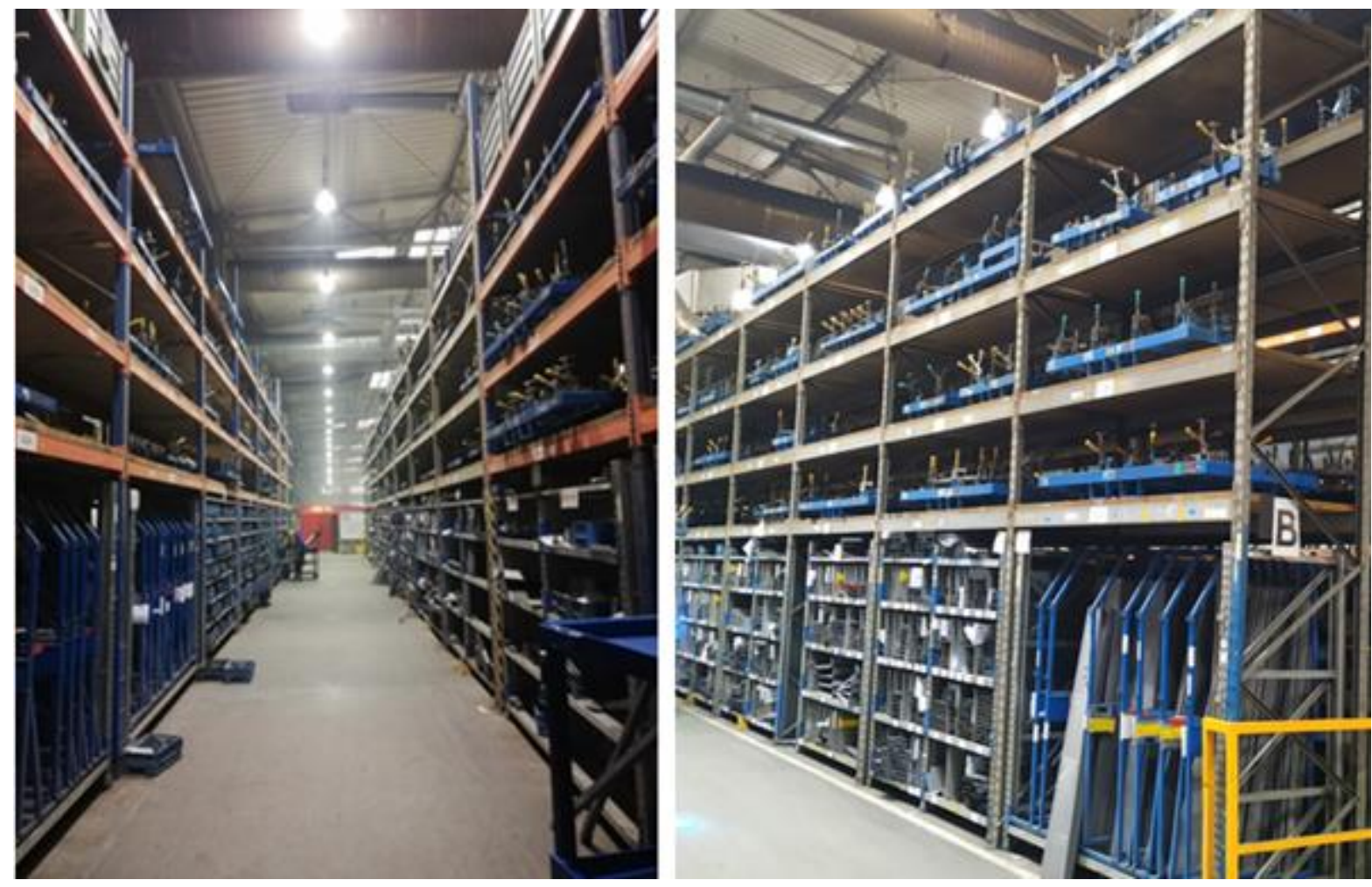

Obrázek 1 - Současný regálový sklad 


\subsection{Prostorová analýza současného skladu}

Prostorová analýza byla provedena, aby byla zjištěna plocha původního regálového skladu. Tato analýza obsahuje tyto parametry:

- Velikost plochy regálů se svařovacími prípravky

- Velikost uličky mezi regály

- Celková velikost plochy regálového skladu

- Velikost ložné plochy celého regálového skladu

Pro výpočet velikosti plochy regálů se svařovacími prvky se přeměřila velikost jednoho regálu a byl spočítán počet všech regálů. Při průzkumu bylo zjištěno, že $v$ jedné řadě před kancelářemi je 9 regálů a zbylé dvě řady jsou po 10 regálech. Celkově tedy vychází, že sklad přípravků se skládá z 29 regálů. Rozměry každého regálu jsou znázorněny $v$ následující tabulce:

Tabulka 1 - Velikost regálu

\begin{tabular}{|c|c|}
\hline Šírka & $2,8 \mathrm{~m}$ \\
\hline Hloubka & $1,1 \mathrm{~m}$ \\
\hline Výška & $5 \mathrm{~m}$ \\
\hline Počet polic & 4 \\
\hline
\end{tabular}

Výpočet plochy jednoho regálu je následující (1):

$$
P_{1}=\text { Šír } k a * H l o u b k a=2,8 * 1,1=3,08 m^{2}
$$

Celková plocha regálů se spočitá vynásobením plochy jednoho regálu jejich počtem dle (2):

$$
P_{\text {reg }}=P_{1} * 29=3,08 * 29=89,32 m^{2}
$$

Dalším parametrem pro výpočet celkové plochy skladu je velikost plochy uličky. Ta má následující rozměry:

- Délka $=25 \mathrm{~m}$

- S Śírka = 3,2 m

Výpočet plochy uličky je pak následovný (3):

$$
P_{u}=D \text { élka } * \text { Šír } k a=25 * 3,2=80 \mathrm{~m}^{2}
$$

Celková plocha regálového skladu je poté součtem plochy regálů a plochy manipulační uličky dle (4):

$$
P_{\text {celk }}=P_{\text {reg }}+P_{u}=89,32+80=169,32 \mathrm{~m}^{2}
$$


Dále byla vypočítána celková ložná plocha regálového skladu. Toho bylo docíleno roznásobením celkové plochy regálů a počtem polic $v$ regále. $\checkmark$ našem případě je tento počet 4 . Výpočet celkové ložné plochy je následující (5):

$$
P_{\text {ložná }}=P_{\text {reg }} * \text { počet polic }=89,32 * 4=357,28 \mathrm{~m}^{2}
$$

Z prostorové analýzy vyplývá, že regálový sklad se svařovacími prípravky zabírá $169,32 \mathrm{~m}^{2}$ plochy ve výrobě. Velký podíl na této ploše má ulička mezi jednotlivými regály. Další vypočtenou plochou byla celková ložná plocha nynějšího skladu, který má velikost $357,28 \mathrm{~m}^{2}$. Prostorová analýza potvrdila, že prostor, který zabírá současný regálový sklad je príliš velký a bylo by vhodné jej díky skladovacímu systému minimalizovat. Zbylý prostor, který bude ušetřen, je možné dále využívat jako nová pracoviště.

\subsection{Analýza přípravků}

Další potřebnou analýzou byla analýza svařovacích prípravků. Svařovací prípravky jsou rozděleny do třech hlavních skupin:

- Malé - budou skladovány ve skladovacím systému

- Střední - volně ložené na hale, či mimo ni

- Velké - umístěné prímo na pracovištích

Při této analýze bylo potřeba přeměřit veškeré svařovací prrípravky, které se měli nacházet ve vhodném skladovacím systému. Nejprve však bylo potřeba určit, které prípravky to budou. $V$ současné době se na hale výroby nachází přes 200 prrípravků. Některé z prípravků nejsou využívány a některé budou odstraněny, či převezeny na druhou halu výroby. Po vytřídění bylo zjištěno, že uskladněno bude 94 prípravků. Právě tyto prípravky byly dále změřeny, aby bylo zjištěno, jak velký skladovací systém bude třeba uvažovat. Rozměry prrípravků byly zapisovány $v$ dimenzích: šiřka, hloubka a výška. Dalším parametrem bylo uzpůsobení pro manipulaci s vysokozdvižným vozíkem. To znamená, že některé přípravky mají tzv. „uši“, za které je možné s př́ípravky pomocí VZV manipulovat. Některé přípravky tyto uši měli, některé ne, ale je možné je přidělat a u některých tato možnost není. Bohužel nebylo možné zakomponovat do tabulky hledisko frekvence využívání, protože to je velice různorodé. Po naměření všech príípravků, byly tyto prípravky rozděleny do několika skupin dle výšky, šířky a hloubky. V následující tabulce jsou vidět počty prípravků $v$ daných skupinách: 
Tabulka 2 - Rozdělení prípravků do skupin

\begin{tabular}{|l|l|l|}
\hline \multicolumn{3}{|c|}{ Skupina dle výšky $v \mathrm{~cm}$} \\
\hline A & $0-40$ & 18 \\
\hline$B$ & $41-50$ & 44 \\
\hline C & $51-60$ & 15 \\
\hline D & $61-70$ & 8 \\
\hline E & $71-80$ & 2 \\
\hline
\end{tabular}

\begin{tabular}{|l|l|l|}
\hline \multicolumn{3}{|c|}{$\begin{array}{c}\text { Skupina dle šiřky } \\
\text { v cm }\end{array}$} \\
\hline 1 & $151-300$ & 30 \\
\hline 2 & $76-150$ & 51 \\
\hline 3 & $0-75$ & 6 \\
\hline
\end{tabular}

\begin{tabular}{|l|l|l|}
\hline \multicolumn{3}{|c|}{$\begin{array}{c}\text { Skupina dle } \\
\text { hloubky v cm }\end{array}$} \\
\hline 1 & $0-60$ & 36 \\
\hline 2 & $61-120$ & 51 \\
\hline
\end{tabular}

Při naměřování svařovacích přípravků byly zjištěny maximální rozměry prípravku. Ty jsou následující:

Tabulka 3 - Maximální rozměry príipravků

\begin{tabular}{|l|r|}
\hline \multicolumn{2}{|l|}{ Maximální rozměry přípravků } \\
\hline Šírka & 300 \\
\hline Hloubka & 120 \\
\hline Výška & 78 \\
\hline
\end{tabular}

Maximální rozměry byly výchozím bodem pro výběr vhodného skladovacího systému a vhodného dodavatele.

\section{$3 \quad$ Návrh skladovacího systému}

Při výběru vhodného skladovacího systému bylo nejprve potřeba zvolit, jaký typ skladovacího systému bude pro skladování svařovacích prípravků nejvhodnější. Dále bylo potřeba zvolit dodavatele, který by tento systém dodal.

\subsection{Volba systému skladování}

Pro uskladnění svařovacích prípravků byly uvažovány dvě varianty skladovacích systémů:

- Vertikální karuselový systém

- Vertikální výtahový systém

Při volbě skladovacího systému bylo potřeba uvažovat, že na police tohoto systému budou umist'ovány těžké a objemné přípravky. Karuselový systém, kde se veškeré police točí kolem osy, by takto těžké prípravky nejspíše neutáhl, nebo by to bylo velice nákladné. Taktéž nakládání a vykládání prípravků by bylo velice pomalé. Naproti tomu vertikální výtahový systém je 
na těžké předměty konstruován. Po společné konzultaci s vedením společnosti, které taktéž souhlasilo s volbou, bylo zvoleno, že nejvhodnějším systémem bude vertikální výtahový systém. Jedním z důvodu zavedení tohoto systému byla zkušenost společnosti s několika dalšími vertikálními výtahovými systémy.

\subsection{Výběr dodavatele}

Mezi nejznámější společnosti, specializující se na výrobu vertikálních výtahových systémů a ze kterých bylo vybíráno, patří:

- Jungheinrich

- Modula

- Remstar

Východiskem pro základní parametry, které by měl daný vertikální výtahový systém mít, byla datová analýza, respektive výsledky této analýzy. Hlavními parametry byly rozměry největšího svařovacího prípravku. Tyto rozměry byly základem pro volbu polic základního výtahového systému, který byl uvažován pro porovnání výhodnosti dodavatelů. Pro specifikování požadavků byly zvoleny následující vlastnosti: výška, maximální rozměry polic, nosnost polic, zabraná plocha skladu, počet výdejních oken, software, cena zakladače, software a napojení, celková cena, záruka, cena za $1 \mathrm{~m} 2$ skladovací plochy, počet dovezených polic za hodinu a cena skladování jednoho kusu. Porovnání dodavatelů a vlastností jimi vyráběného výtahového systému jsou v následující tabulce:

Tabulka 4 - Volba dodavatele [1][2][3]

\begin{tabular}{|l|c|c|c|c|}
\cline { 2 - 5 } \multicolumn{1}{c|}{} & \multicolumn{2}{c|}{ MODULA } & JUNGHEINRICH & REMSTAR \\
\hline Typ vertikálního systému & MX 75D & ML 75D & LRK & Shuttle XP 1000 \\
\hline Výška [mm] & 8100 & 8100 & 8150 & 8050 \\
\hline Rozměr polic [mm] & $3100 \times 1220$ & $4100 \times 1220$ & $3650 \times 1270$ & $3050 \times 1778$ \\
\hline Nosnost polic [kg] & 750 & 750 & 450 & 460 \\
\hline Zabraná podlahová plocha skladu [m^2] & 11,13 & 14,3 & 11,6 & 19,09 \\
\hline Počet výdejních oken & 1 & 1 & 1 & 1 \\
\hline Software & Vlastní WMS & Vlastní WMS & Middleware interface & Power Pick Global \\
\hline Základní cena výtahového systému & $53175 €$ & $58000 €$ & $48370 €$ & $45940 €$ \\
\hline Software a napojení & Neuvedeno & Neuvedeno & 5 990€ & $2850 €$ \\
\hline Celková cena & $53175 €$ & $58000 €$ & $54360 €$ & $48790 €$ \\
\hline Záruka [měs] & 12 & 12 & 12 & 24 \\
\hline Počet dovezených polic za hodinu & 81 & 81 & 88 & 87 \\
\hline Cena za skladování 1 svař. Přípravku & $571,77 €$ & $623,66 €$ & $584,52 €$ & $524,62 €$ \\
\hline
\end{tabular}

Z tohoto porovnání je patrné, že nejvýhodnějším dodavatelem je společnost Remstar s výtahovým systémem Shuttle XP 1000. Velikost police tohoto systému je 3050x1778 mm, což je dostačující i pro největší svařovací 
prípravek. Obrovskou výhodou tohoto systému jsou doplňky, které společnost Remstar nabízí. Mezi ty nejhlavnější patří například automatický stůl, který dovoluje zaskladňování $\mathrm{i}$ velkých palet s objemnými břemeny. Dále je to např́klad jeřáb, který je přimontován na konstrukci před výdejním oknem a díky kterému je možné manipulovat se skladovanými břemeny.

\section{$4 \quad$ Umístění svařovacích přípravků}

Poté co byl zvolen vertikální výtahový systém Shuttle XP 1000 od společnosti Remstar, bylo potřeba zjistit, jaké atributy by měl tento systém mít. Základní atributy kardexu (jiný název pro vertikální výtahové systémy) jsou v následující tabulce:

Tabulka 5 - Vlastnosti zvoleného výtahového systému

\begin{tabular}{|c|c|c|c|}
\hline \multicolumn{4}{|c|}{ Rozměry systému } \\
\hline & Min & $\operatorname{Max}$ & \\
\hline Šířka & 1580 & 4380 & $\mathrm{~mm}$ \\
\hline Hloubka & 2362 & 4343 & $\mathrm{~mm}$ \\
\hline Výška & 2550 & 20050 & $\mathrm{~mm}$ \\
\hline \multicolumn{4}{|c|}{ Rozměry polic } \\
\hline & Min & Max & \\
\hline Šířka & 1250 & 4050 & $\mathrm{~mm}$ \\
\hline Hloubka & 610 & 1778 & $\mathrm{~mm}$ \\
\hline \multicolumn{4}{|c|}{ Nosnost polic } \\
\hline \multicolumn{2}{|c|}{ Šíŕka police } & \multicolumn{2}{|c|}{ Nosnost police } \\
\hline \multicolumn{2}{|c|}{$1250 \mathrm{~mm}$} & \multicolumn{2}{|c|}{$1000 \mathrm{~kg}$} \\
\hline \multicolumn{2}{|c|}{$2450 \mathrm{~mm}$} & \multicolumn{2}{|c|}{$900 \mathrm{~kg}$} \\
\hline \multicolumn{2}{|c|}{$4050 \mathrm{~mm}$} & \multicolumn{2}{|c|}{$800 \mathrm{~kg}$} \\
\hline \multicolumn{4}{|c|}{ Maximální nosnost systému } \\
\hline \multicolumn{4}{|c|}{120 tun } \\
\hline \multicolumn{4}{|c|}{ Výškový rastr systému } \\
\hline \multicolumn{4}{|c|}{ Kroky po $100 \mathrm{~mm}$} \\
\hline \multicolumn{4}{|c|}{ Vertikální rychlost zakladače } \\
\hline & 0,7 & $\mathrm{ls}$ & \\
\hline
\end{tabular}

Tyto atributy byli východiskem pro experimenty s rozmístěním svařovacích prípravků na police výtahového systému. Při těchto experimentech bylo hlavní myšlenkou fixní rozmístění svařovacích přípravků, což znamená, že každý př́pravek by měl přesně danou pozici a místo, kde by měl být umístěn. Je to hlavně $z$ toho důvodu, aby bylo možné maximálně využít prostoru uvnitř výtahového systému. Zjednodušeně to znamená, že prípravky se ručně 
umist'ovali vedle sebe tak, aby jejich výška byla co nejvíce podobná (cca do $10 \mathrm{~cm}$ ) a součet šiřrek obou prípravků nepřesáhl velikost police.

Při experimentování s umístěním přípravků byly vytvořeny dva hlavní způsoby rozmístění: prípravky skladované vedle sebe a prípravky skladované vedle sebe i za sebe. Princip je zřejmý z následujících obrázků.

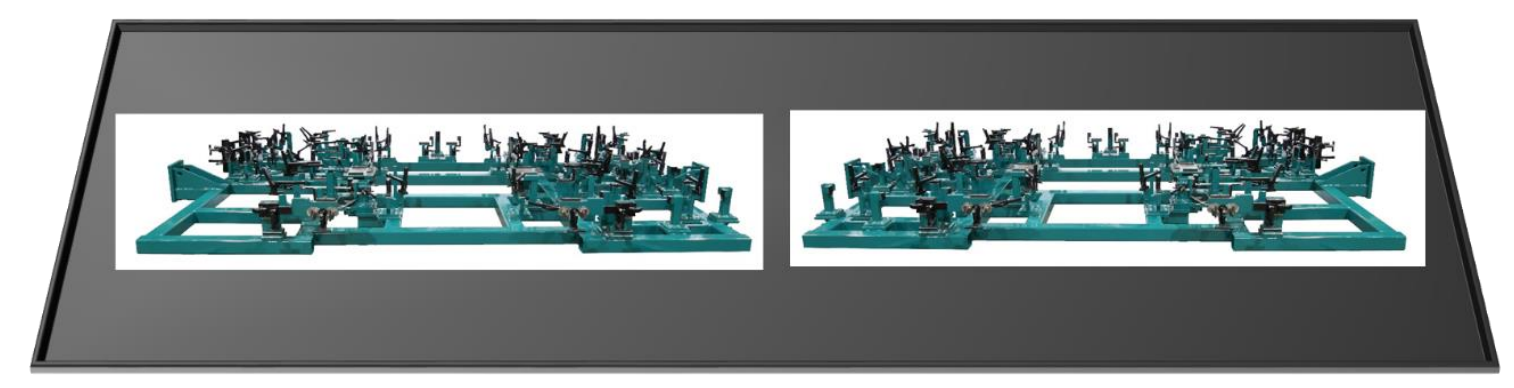

Obrázek 2 - Skladování vedle sebe

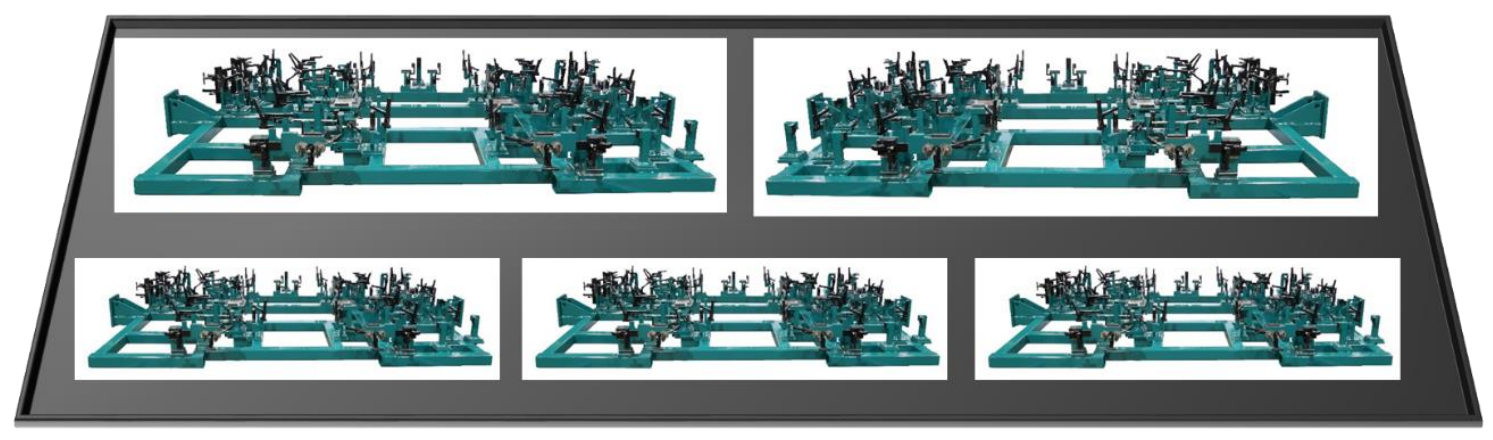

Obrázek 3 - Skladování vedle sebe i za sebe

Každá z těchto variant má své výhody a nevýhody. Výhodou u skladování př́pravků vedle sebe má hlavní výhodu $v$ jednoduchosti manipulace se svařovacími přípravky. Další výhodou je menší zastavěná plocha skladovacím systémem. Nevýhodou je pak tzv. „skladování vzduchu“ a obrovská výška, kterou by skladovací systémy museli mít. U skladování přípravků vedle sebe i za sebe je maximálně využit potenciál vertikálního výtahového systému při malých výškách kardexu. Nevýhodou je pak složitá manipulace, kterou je potřeba řešit dalšími možnostmi.

\subsection{Experimenty s umístěním}

Při experimentování s rozmístěním svařovacích př́ípravků bylo vytvořeno 5 variant $s$ různými velikostmi polic. Tři $z$ těchto variant uvažovali skladování prípravků pouze vedle sebe a zbylé dvě skladování vedle sebe i za sebe. Jak již bylo zmíněno, veškeré přípravky bylo nutné umístit ručně na dané police, tak aby byla maximálně využita kapacita. Toto bylo zpracováno $v$ tabulkách Excelu, kde se automaticky vyplňovali rozměry všech př́ipravků uložených na dané polici. 
Tabulka 6 - Varianty rozmístění prípravků

\begin{tabular}{|l|c|c|c|c|c|}
\cline { 2 - 6 } \multicolumn{1}{c|}{} & \multicolumn{3}{c|}{ Vedle sebe } & \multicolumn{2}{c|}{ Vedle sebe + za sebe } \\
\cline { 2 - 6 } \multicolumn{1}{c|}{} & Varianta 1 & Varianta 2 & Varianta 3 & Varianta 4 & Varianta 5 \\
\hline Šířka police & $320 \mathrm{~cm}$ & $395 \mathrm{~cm}$ & $405 \mathrm{~cm}$ & $405 \mathrm{~cm}$ & $405 \mathrm{~cm}$ \\
\hline Hloubka police & $130 \mathrm{~cm}$ & $130 \mathrm{~cm}$ & $130 \mathrm{~cm}$ & $178 \mathrm{~cm}$ & $130 \mathrm{~cm}$ \\
\hline Výška systému & $13,5 \mathrm{~m}$ & $11,5 \mathrm{~m}$ & $10,5 \mathrm{~m}$ & $6,2 \mathrm{~m}$ & $8,25 \mathrm{~m}$ \\
\hline
\end{tabular}

Z tabulky výše je vidět, že pro umístění výtahového systému na halu výroby je možné uvažovat pouze varianty, ve kterých se skladují přípravky vedle sebe i za sebe. Pro volbu nejvýhodnější varianty byla vytvořena vícekriteriální rozhodovací tabulka. Tato tabulka se rídí následujícími pravidly:

- Váha faktorů - 1 nejméně, 5 nejvíce

- Bodování variant - 1 nejlepší, 10 nejhorší

- CCím nižší je celkový součet, tím výhodnější je varianta

Tabulka 7 - Rozhodovací tabulka s variantami rozmístění prípravků

\begin{tabular}{|c|c|c|c|c|}
\hline Faktor & Váha & $\begin{array}{c}\text { Varianta vedle } \\
\text { sebe } \\
(405 \times 130 \mathrm{~cm})\end{array}$ & $\begin{array}{c}\text { Varianta vedle } \\
\text { sebe + za sebe } \\
(405 \times 178 \mathrm{~cm})\end{array}$ & $\begin{array}{c}\text { Varianta vedle } \\
\text { sebe + za sebe } \\
(405 \times 130 \mathrm{~cm})\end{array}$ \\
\hline Náklady & 5 & 4 & 8 & 7 \\
\hline $\begin{array}{c}\text { Využití skladovací } \\
\text { plochy }\end{array}$ & 4 & 8 & 2 & 2 \\
\hline $\begin{array}{c}\text { Zastavěná plocha } \\
\text { dažnośch umístění }\end{array}$ & 3 & 3 & 7 & 5 \\
\hline Manavků & 3 & 8 & 2 & 6 \\
\hline Celkem & 2 & 2 & 3 & 3 \\
\hline
\end{tabular}

Z tabulky výše, vychází nejlépe varianta $4, \mathrm{~s}$ umístěním prípravků vedle sebe $\mathrm{i}$ za sebe a s rozměry polic 4050 x $1778 \mathrm{~mm}$. Jako vítězná varianta však byla zvolena varianta 5 , která splňuje veškeré požadavky na skladovací systém. Navíc je tato varianta méně nákladná a zabírá méně prostoru, což je největší výhodou. Tato varianta má následující vlastnosti:

- Skladování prípravků vedle sebe i za sebe

- Rozměry polic - 4050 x 1300 mm

- Výška kardexu - cca 8,25 m 
Jak již bylo dříve zmíněno, varianty s umístěním přípravků vedle sebe i za sebe mají zásadní nevýhodu ve složitosti manipulace se svařovacími přípravky. Tato složitost je hlavně s príipravky umístěnými v zadní řadě, které není možné jednoduše vzít a vyskladnit. $Z$ toho důvodu bylo nutné navrhnout řešení, které by tuto manipulaci zjednodušovalo.

Jedním z řešení je již dřive zmíněný jeřáb umístěný na konstrukci před výdejním oknem. Tím to jeřábem by bylo možné přemístit prípravky ze zadních řad prímo na vysokozdvižný vozík. Tato varianty však manipulaci o moc neulehčuje a časová náročnost na přemístění přípravků je vysoká. Další možností by bylo výdejní okno na druhé straně kardexu. Toto výdejní okno je však velice nákladné a s dalším výdejním oknem by se musela výška kardexu zvýšit a ten by se zřejmě již nevešel na halu výroby. Třetí možností by bylo umístění otočného stolu před stůl výdejní. Celá police by se na tento stůl umístila a pootočila $\circ 90^{\circ}$, aby bylo možné nabrat prípravky z druhé raady. Tato varianta by zabírala velké množství plochy, jelikož při pootočení stolu by se zastavěla celá šíŕka police, která činí $4,05 \mathrm{~m}$. Poslední možností by bylo umístění dopravníku vedle výdejního stolu. $\mathrm{Na}$ tento dopravník by se poté přesunula celá police a bylo by možné nabrat prípravky zezadu. Pro porovnání těchto variant byla vytvořena následující tabulka, která se řídí podle stejných pravidel, jako dříve zmíněná vícekriteriální tabulka.

Tabulka 8 - Vyhodnocení varianty pro zjednodušení manipulace

\begin{tabular}{|l|c|c|c|c|c|}
\hline \multicolumn{1}{|c|}{ Faktor } & Váha & Jeřáb & $\begin{array}{c}\text { Druhé } \\
\text { výdejní } \\
\text { okno }\end{array}$ & $\begin{array}{c}\text { Otočný } \\
\text { stůl }\end{array}$ & Dopravník \\
\hline Náklady & 5 & 3 & 8 & 5 & 4 \\
\hline Potřebná plocha & 3 & 1 & 1 & 6 & 3 \\
\hline Složitost manipulace & 2 & 8 & 1 & 4 & 2 \\
\hline Časová náročnost & 3 & 8 & 1 & 4 & 3 \\
\hline \multicolumn{2}{|c|}{ Celkem } & $\mathbf{5 8}$ & $\mathbf{4 8}$ & $\mathbf{6 3}$ & $\mathbf{4 2}$ \\
\hline
\end{tabular}

Z této tabulky je jasně patrné, že nejvýhodnější variantou je varianta s dopravníkem umístěným vedle výdejního stolu.

\subsection{Bezpečnostní prvky}

Aby bylo možné zabránit poškození vertikálního výtahového systému, bylo potřeba vymyslet, jaké bezpečnostní prvky by bylo možné implementovat. Samozřejmostí je značení na podlaze, které vymezuje pozici výtahového systému. Dále to jsou značení vymezující prostor pro manipulaci a prostor pro údržbu výtahového systému. Pro snižení rizika najetí na kardex, by měly být před výdejním oknem, či před výše zmiňovaným dopravníkem umístěny zábrany, které by tomuto zamezili. Zábrany je vhodné umístit tak, aby bylo možné nabrat na vidlice vozíku potřebné svařovací přípravky, ale aby nebylo 
možné najet celým vysokozdvižným vozíkem do míst, kde jsou tyto prípravky vychystávány. Na následujícím obrázku, je vidět možný typ zábran.

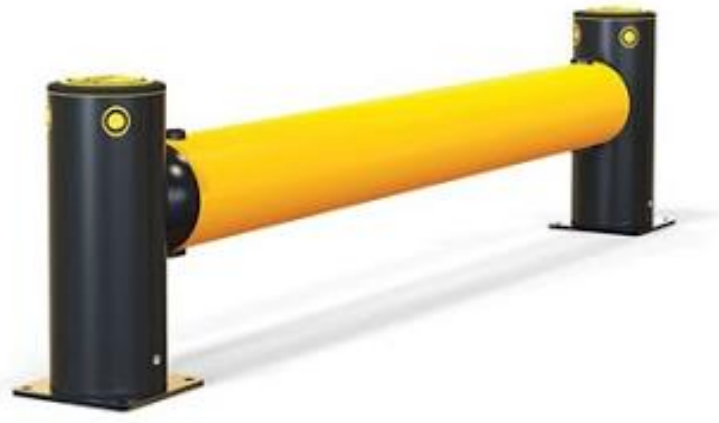

Obrázek 4 - Zábrany [4]

Další spíše vizuální bezpečnostní prvky, které je vhodné zavést, jsou majáčky, které by blikaly, pokud by byla vychystávána nějaká police.

\section{$5 \quad$ Vyhodnocení zvolené varianty}

Po závěrečném rozhodnutí finální varianty, je potřeba zhodnotit navržený stav oproti tomu současnému. Jak již bylo popsáno dřive, nejvýhodnějším dodavatelem pro zavedení vertikálního výtahového systému do firmy je společnost Remstar s výtahovým systémem Kardex Shuttle XP 1000. Při následných analýzách různých variant skladování svařovacích přípravků, se jako nejvýhodnější varianta stala ta s rozmístěním prípravků vedle sebe i za sebe a s rozměry polic $4050 \times 1300 \mathrm{~mm}$.

Je jasné, že nejvíce se navržený výtahový systém projeví v podobě úspory místa. Takto uspořený prostor je možné, jak již bylo dřive zmíněno, využít pro další pracoviště. $V$ tabulce níže je poměr současné plochy regálového skladu a plochy, kterou by zabíral navržený vertikální výtahový systém.

Tabulka 9 - Porovnání uspořené plochy

\begin{tabular}{|c|c|}
\hline & Plocha \\
\hline Současný stav skladu & $169,32 \mathrm{~m}^{2}$ \\
\hline $\begin{array}{c}\text { Navržený výtahový } \\
\text { systém }\end{array}$ & $27,74 \mathrm{~m}^{2}$ \\
\hline Uspořená plocha & $141,58 \mathrm{~m}^{2}$ \\
\hline
\end{tabular}

Do této tabulky však není započíána potřebná plocha pro dopravník a manipulační plocha pro vysokozdvižné vozíky. Je zde počítáno pouze s celkovou plochou výtahového skladovacího systému a plochou výdejního stolu umístěného před výdejní okno. Uspořená plocha by tedy byla ještě o něco nižší, avšak stále dostačující pro zavedení několika pracovišt'. 
Zavedením výtahového skladovacího systému je možné ušetřit velké množství času, které je zpưsobenou ztrátami, které jsou způsobeny ztrátami, kterých se manipulant při manipulaci dopouští. Mezi tyto ztráty nejvíce patří hledání svařovacího prrípravku, zaskladňování př́ípravků na své pozice a vyskladňování prípravků, napríklad z nejvyšších pozic. Tyto činnosti, jak bylo zjištěno $z$ časových snímků, dělají $v$ součtu přes $16 \%$ z pracovní směny manipulantů. Tyto ztráty by se zavedením systému eliminovali.

\section{Tabulka 10 - Redukovatelné činnosti}

\begin{tabular}{|c|r|}
\cline { 2 - 3 } \multicolumn{1}{c|}{} & Procentuální zastoupeni \\
\hline Zaskladňování přípravku do skladu & $3,31 \%$ \\
\hline Vyskladňování prípravku ze skladu & $1,98 \%$ \\
\hline Hledání príipravku & $10,87 \%$ \\
\hline
\end{tabular}

Jak již bylo několikrát zmíněno, zavedením vertikálního výtahového systému by bylo možné využít uspořenou plochu pro zavedení nových pracovišt', které by zvýšili objem výroby. Díky tomu by byla doba návratnosti investice rapidně snižena. Produkce by se zvýšila taktéž díky zrychlení zavážení pracovišt' svařovacími přípravky, kdy v současné době pracovníci čekají dlouhou dobu, než jim je požadovaný prípravek dovezen.

\section{Závěr}

Tento článek popisuje postup při navrhování způsobu skladování přípravků. Návrh byl vytvořen hlavně z důvodu úspory místa na hale výroby společnosti. Aby bylo docíleno finální varianty uskladnění, byla nejprve provedena analýza současného stavu, která obsahovala prostorovou, datovou a časovou analýzu. $V$ těchto analýzách bylo zjištěno, jakým způsobem a na jaké ploše se skladují přípravky $v$ současné době. Další částí této analýzy bylo naměření všech svařovacích prípravků, které mají být umístěny do zvoleného skladovacího systému.

Dalším krokem byla volba vhodného skladovacího systému a vhodného dodavatele pro tento systém. Po rozhodnutí o vhodném skladovacím systému bylo provedeno několik experimentů, které měli za cíl navrhnout rozmístění všech svařovacích přípravků na police skladovacího systému. $Z$ těchto experimentů byla vybrána jedna varianta, která byla zvolena jako nejvýhodnější. Po volbě finální varianty bylo potřeba zajistit realizovatelnost manipulačních činností se svařovacími prípravky. Posledním bodem pro návrh vhodného skladovacího systému bylo navržení bezpečnostních prvků.

$\mathrm{Na}$ následujícím obrázku je vizualizovaná výsledná varianta vertikálního výtahového systému i s doplňky. 


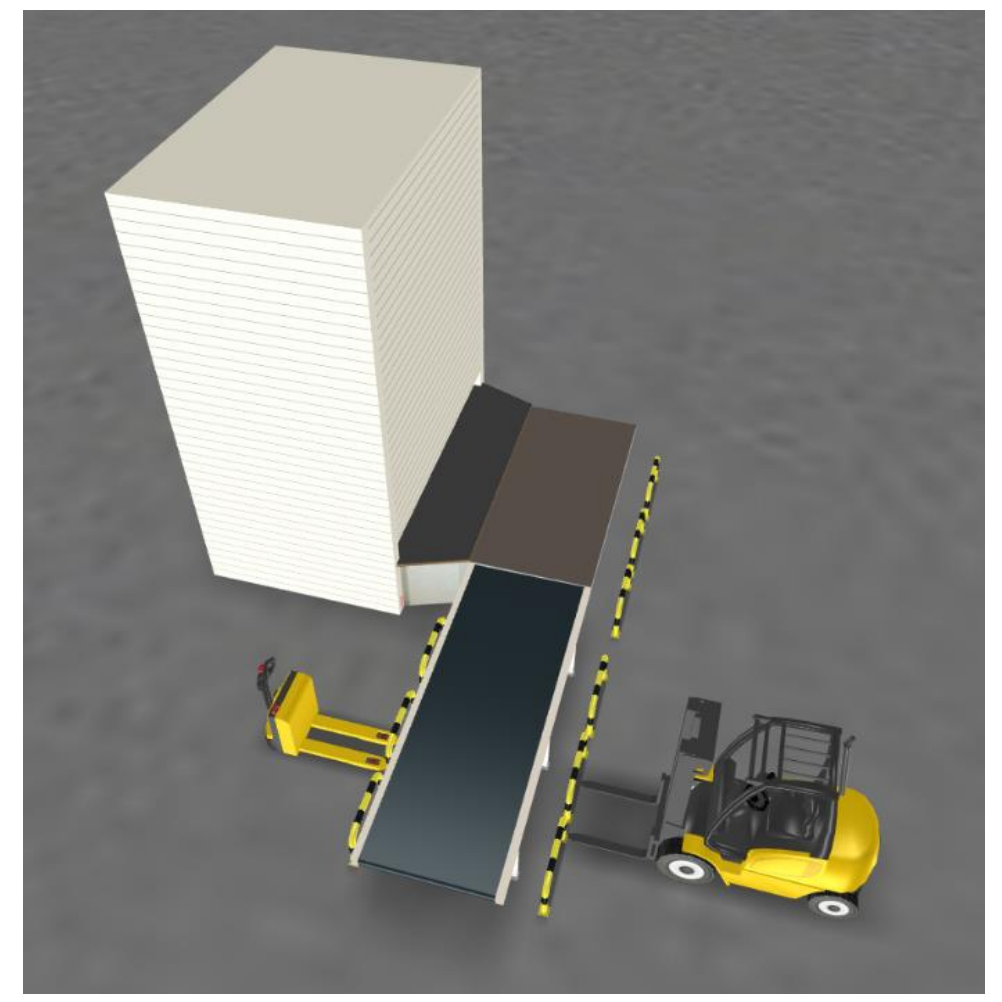

Obrázek 5 - Finální varianta

\section{Poděkování}

Tento článek byl vytvořen za podpory interního grantu Západočeské univerzity číslo projektu je SGS-2018-031 s názvem Optimalizace parametrů udržitelného výrobního systému.

\section{Použitá literatura}

[1] MODULA. Modula Lift. [Online] [Citace: 22. 6. 2020.] https://www.modula.eu/ces/produkty/modula-lift.html.

[2] Jungheinrich. Výtahový regál - LRK. [Online] [Citace: 22. 6. 2020.] https://www.jungheinrich.cz/produkty/regaly/dynamicke-skladovanidrobnych-dilu/vytahovy-regal-492410.

[3] Kardex Remstar. Kardex Remstar Shuttle XP 1000. [Online] [Citace: 29. 6. 2020.] https://www.kardex-remstar.cz/cz/automatizovane-skladovesystemy/vertikalni-vytahove-systemy/shuttle-xp-1000.html.

[4] A-SAFE. Bezpečnostní zábrany pro oddělení manipulační techniky. [Online] [Citace: 3. 7. 2020.] http://bezpecnostnizabranyasafe.cz/bezpecnostnizabrany/bezpecnostni-zabrany-oddeleni-manipulacni-techniky/. 